\title{
THE LOCAL STRESS STATE OF THE PIPELINE WITH AXIAL AND ANGULAR WELD MISALIGNMENT
}

\author{
Yaroslav Dubyk $^{1}$; Iryna Seliverstova ${ }^{2}$ \\ ${ }^{1}$ LLC. «IPP-Centre», Kyiv, Ukraine \\ ${ }^{2}$ G. S. Pisarenko Institute for Problems of Strength of the NAS of Ukraine, \\ Kyiv, Ukraine
}

Summary. The paper is devoted to the evaluation of the stressed state of the shell containing two common defects in the weld shape - angular and axial misalignment at the same time. Expressions for stress resultants and stress concentration factors for axial and angular misalignment are proposed. The analytical approach is tested by means of numerical calculations for the internal pressure.

Key words: axial misalignment, angular misalignment, stress concentration coefficient, finite element method, cylindrical shell.

https://doi.org/10.33108/visnyk_tntu2019.02.051

Received 03.05.2019

Introduction. Pipeline sections welding is the most important operation which greatly determines the quality of the carried out work. Pipeline sections welding is also the most essential technical operation affecting the structure quality and reliability. During welding it is necessary to provide pipes alignment achieved by qualitative welding edges alignment and assuring uniform gap between the joints for uniform root welding along the whole perimeter. In practice of constructing large-diameter pipelines it is difficult to comply with all welding specifications and avoid major defects in the weld shape.

In previous publications we have analyzed stress state of pipes with shape defects in weld areas, such as: angular misalignment [1] and wall thickness variation (axial misalignment) [2]. According to [3] within tolerance weld joint of two pipe sections with angular misalignment $\theta$ up to 3 degrees is accepted. The axial misalignment, which is the most common welding defect and is characterized by absolute joint displacement value $e$ or dimensionless value $\Delta=e / t \Delta=\mathrm{e} / \mathrm{t}$, ( $\mathrm{t}$ is pipe wall thickness) in practice often exceed the accepted value. This is due to the fact that joint alignment process results, on the one hand, in the increase of welded elements assembly complexity and, on the other hand, in posible decrease of equipment service life caused by additional tension stresses [4]. Thickness variation of the connecting branches with wall thickness ratio greater than 1,5 is considered to be a defect [5]. Usually the smooth transition from one section to another with inclination angle which does not exceed 15 degrees should be provided in butt welds of pipes with different nominal thickness [6]. For aboveground pipelines the defect of axial misalingment type with the dimension up to $25 \%$ of wall thickness in most standards is acceptable for service.

The analytical method of force and strain parameters determination for stress state (SS) of pipes with cicumferential weld imperfections in the form of axial misalignments was obtained in paper [2] on the basis of shell solutions. The accuracy of analytical approach was verified by numerical calculation. The analytical solution of pipeline stress state determination in the area of the weld axial misalignments under the action of internal pressure and bending 
moment demonstrated by means of experimental and numerical data comparison was derived in paper [1].

This work is an extension of the previuos woks in this direction, considering combined form defect which contains angular and axial misalignment at the same time. It is reasonably common defect for welded pipelines.

Let us consider the stress strain state of the pipe joint by circumferential weld containing such defects as axial and angular misalingments (Fig. 1). The sections have the saame wall thickness and different radii. Using the superposition principle the resultant stress state is the sum of SSS of two pipes: separately with angular and separately with axial misalignment (Fig. 1).
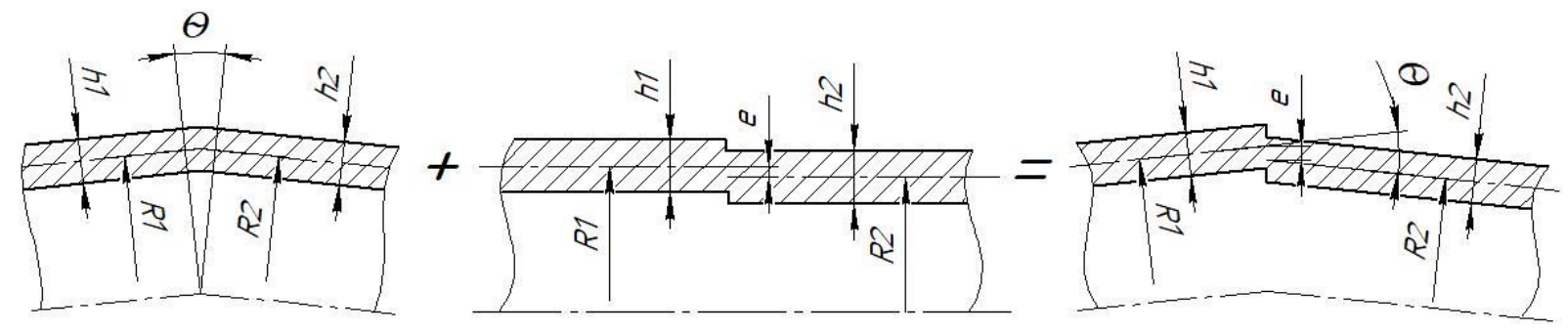

Figure 1. Scheme of the axial and angular missaligments: $R$ - the average shell radius, $h$ - the shell wall thickness, $e$ - the absolute displacement of the weld edges, $\theta$ - angle missalignments

Basic mathematical dependencies. The equation of the cylindrical shell equilibrium is well-known [7]:

$$
\begin{gathered}
\frac{\partial N_{x}}{\partial x}+\frac{\partial L}{R \partial \varphi}=0, \\
\frac{\partial N_{\varphi}}{R \partial \varphi}+\frac{\partial L}{\partial x}+\frac{Q_{\varphi}}{R}=0, \\
\frac{\partial Q_{x}}{\partial x}+\frac{\partial Q_{\varphi}}{R \partial \varphi}-\frac{N_{\varphi}}{R}=0
\end{gathered}
$$

where $N_{x}, N_{\varphi}$ - are axial and circular forces, $L$ - is tangential force, $Q_{x}, Q_{\varphi}$ - are lateral forces.

It is shown in paper $[1,8]$ that general solution (1)-(3) can be obtained by dividing the system into two separate ones: short solution, which rapidly damps along the axial coordinate and long solution which is slowly damped in axial direction. In case of axial and angular misalignment analysis under internal pressure action it is enough to have only short solution.

The short solution is characterized by four main parameters: radial displacement $w$, rotation angle $\gamma_{x}$, axial bending moment $M_{x}$, and lateral force $Q_{x}$. The final dependencies of the short solution $[1,8]$ required in our analysis are given below:

$$
\begin{gathered}
w=\left(C_{1} F_{1}(x)+C_{2} F_{2}(x)\right) \cos (n \varphi) \\
\gamma_{x}=-\left(C_{1}\left(-a F_{1}(x)-b F_{2}(x)\right)+C_{2}\left(-a F_{2}(x)+b F_{1}(x)\right)\right) \cos (n \varphi)
\end{gathered}
$$




$$
\begin{gathered}
\left.M_{x}=H \delta\left(\begin{array}{l}
\left(C_{1}\left(F_{1}(x)\left((a)^{2}-(b)^{2}\right)+2 a b F_{2}(x)\right)+\right. \\
C_{2}\left(F_{2}(x)\left((a)^{2}-(b)^{2}\right)-2 b a F_{1}(x)\right)
\end{array}\right)-\mu \frac{n^{2}}{R^{2}}\left(C_{1} F_{1}(x)+C_{2} F_{2}(x)\right)\right) \cos (n \varphi) \\
Q_{x}(x, \varphi)=D\left(\begin{array}{l}
C_{1}\left(\left(3 c d^{2}-c^{3}\right) F_{1}(x)+\left(d^{3}-3 d c^{2}\right) F_{2}(x)\right)+C_{2}\left(3 c d^{2}-c^{3}\right) F_{2}(x)+ \\
+\left(3 d c^{2}-d^{3}\right) F_{1}(x)-\frac{n^{2}}{R^{2}}\left(C_{1}\left(-c F_{1}(x)-d F_{2}(x)\right)+C_{2}\left(d F_{1}(x)-c F_{2}(x)\right)\right)
\end{array}\right) \cos (n \varphi) \\
N_{x}(x, \varphi)=\frac{n}{\left(a^{2}+b^{2}\right) R}\left[\begin{array}{l}
\left(C_{1}\left(E_{1} a-E_{2} b\right)+C_{2}\left(E_{1} b+E_{2} a\right)\right) F_{1}(x)+ \\
+\left(C_{2}\left(E_{1} a-E_{2} b\right)-C_{1}\left(E_{1} b+E_{2} a\right)\right) F_{2}(x)
\end{array}\right] \cos (n \varphi)
\end{gathered}
$$

The following functions are introduced here $F_{1}(x)=e^{-a_{n} x} \cos \left(b_{n} x\right), F_{2}(x)=e^{-a_{n} x} \sin \left(b_{n} x\right)$, де $\rho \cos \psi=a_{n}, \rho \sin \psi=b_{n}, \rho=\sqrt[4]{B}, \psi=\frac{1}{2} \arccos \left(\frac{A}{\sqrt{B}}\right):$

$$
A=\mu \frac{n^{2}}{R^{2}}, B=\left(\frac{n}{R}\right)^{4}+12 \frac{\left(1-\mu^{2}\right)}{R^{2} h^{2}}
$$

If $n=0$ then the short solution is the well-known axi- symmetrical end effect in cylindrical shells, here $L=N_{x} \equiv 0$.

In case of axial misalignment constants $C_{1}, C_{2}, C_{3}$ and $C_{4}$ are determined from the conditions of section conjugation at the point of their joining:

$$
w_{1}=w_{2}, \gamma_{x 1}=\gamma_{x 2}, Q_{x 1}=Q_{x 2}, M_{x 1}-N e=M_{x 2}
$$

If $n=0$ from (9) we get that $a=b=\alpha$, where notation $\alpha=\sqrt[4]{\frac{3\left(1-\mu^{2}\right)}{R^{2} h^{2}}}$ is introduced, then from (4), (5)-(8) and (10) it is easy to obtain the constants values:

$$
C_{1}=0, C_{2}=-\frac{1}{4} \frac{N e}{H \delta \alpha^{2}}, C_{3}=0, C_{4}=\frac{1}{4} \frac{N e}{H \delta \alpha^{2}},
$$

here $H=\frac{E h}{1-\mu^{2}}, \delta=\frac{h^{2}}{12}, N=-p R / 2$. Knowing the constants $C_{1}, C_{2}, C_{3}, C_{4}$ from (4)-(8) it is easy to get all force components, it should be noted that in this case $M_{\varphi}=\mu M_{x}, N_{x} \equiv 0$ :

$$
\begin{gathered}
N_{\varphi}= \pm N e \alpha^{2} R F_{2}(x) \\
M_{x}= \pm \frac{N e F_{1}(\mathrm{x})}{2}, M_{\varphi}= \pm \frac{N e \mu F_{1}(\mathrm{x})}{2},
\end{gathered}
$$

here sign «+»» refers to the pipe with smaller diameter, and sign «-» with larger one.

Then from (12-13) it is easy to derive the concentration coefficients, $K_{x}$ estimates the stress concentration in axial direction, $K_{\varphi}$ - in circumferential direction: 


$$
\begin{gathered}
K_{x}=\frac{\sigma_{x}}{\sigma_{x}^{\text {ном }}}=1 \pm \frac{6 N e}{p R h} F_{1}(x), \\
K_{\varphi}=\frac{\sigma_{\varphi}}{\sigma_{\varphi}^{\text {ном }}}=1 \pm \frac{\left(\frac{N e \alpha^{2} R F_{2}(x)}{h}+\frac{3 N e \mu F_{1}(x)}{h^{2}}\right)}{p R} h
\end{gathered}
$$

In case of angular misalignment under internal pressure only two forces: $N_{x}^{b}=\frac{-p R}{2}$ and $N_{\varphi}^{b}=-p R$ act on the straight pipe section. Then the following boundary conditions should be used [1]:

$$
L^{\prime} \approx \frac{-p R}{2} \sin \theta \cos \varphi ; Q^{\prime} \approx \frac{p R}{2} \sin \theta \sin \varphi
$$

Taking into account the symmetry, the boundary condition $\left.\gamma_{x}\right|_{x=0}=0$ should be met. In short solution at $n=1$ it is necessary to meet the boundary conditions for $\gamma_{x}, Q_{x}$, as they are the main variable. Analyzing expression (9) for thick shells $R / h>10$ at $n=1$ we can easily understand that $\left(\frac{n}{R}\right)^{4}<12 \frac{\left(1-\mu^{2}\right)}{R^{2} h^{2}}$, and value $\psi \approx \frac{\pi}{4}$ as $\frac{A}{\sqrt{B}} \approx 0$. Thus, we can assume that $a=b=\alpha$ similarly as at $n=0$. Hence from (5), (7) and (16) we derive two constants $C_{1}, C_{2}$ :

$$
C_{1}=\frac{1}{8} \frac{p R \sin (\theta)}{H \delta \alpha^{3}}, C_{2}=\frac{1}{8} \frac{p R \sin (\theta)}{H \delta \alpha^{3}}
$$

If constants $C_{1}, C_{2} 3(4)-(8)$ are known we can easily get all force components, and it should be noted that $M_{\varphi}=\mu M_{x}, N_{x}=0$.

$$
\begin{gathered}
N_{\varphi}=-\frac{1}{2} \alpha p R^{2} \sin (\theta) \cdot\left(F_{1}(x)+F_{2}(x)\right) \\
M_{x}=\frac{1}{4 \alpha} p R \sin (\theta) \cdot\left(F_{2}(x)-F_{1}(x)\right)
\end{gathered}
$$

Then from (18) and (19) we derive the stress concentration coefficients:

$$
\begin{aligned}
& K_{x}=\frac{\sigma_{x}}{\sigma_{x}^{\text {нoM }}}=1+\frac{3}{\alpha h} \sin \theta\left(F_{2}(x)-F_{1}(x)\right) \\
& K_{\varphi}=\frac{\sigma_{\varphi}}{\sigma_{\varphi}^{\text {HoM }}}=1-\frac{1}{2} \alpha R \cdot \sin \theta\left(F_{1}(x)+F_{2}(x)\right)+\frac{3 \mu \sin \theta}{2 \alpha h}\left(F_{2}(x)-F_{1}(x)\right)
\end{aligned}
$$

Numerical verification. The developed analytical approach for SS determination in the weld defect areas was tested by means of numerical modeling. The numerical modeling of axial and angular misalignment was carried out by finite elements (FE) method using ANSYS software. This problem was considered under internal pressure action. 
In order to solve the given problem the shell FE model with idealized angular and axial misalignment was constructed (see Fig. 2). The model mid-radius is $374,65 \mathrm{~mm}$, angle $\theta=4^{\circ}$, wall thickness $t=12,7 \mathrm{~mm}, e=0,8 \mathrm{~mm}$.

The boundary conditions providing the fixing of one pipe end and application of $24390 \mathrm{H}$ force to another end as well as $3,8 \mathrm{MPa}$ internal pressure are used for shell stresses determination. Stress fields occurring in the model with complex defect under pressure are shown in Fig. 2. The calculations proved that the largest stresses occur in the weld area.

The distribution of axial and circumferential forces on the outer and inner surfaces calculated by analytical dependences (12), (13), (18), (19) is represented in Fig. 3. The numerical results are shown in Fig. 3 for comparison.

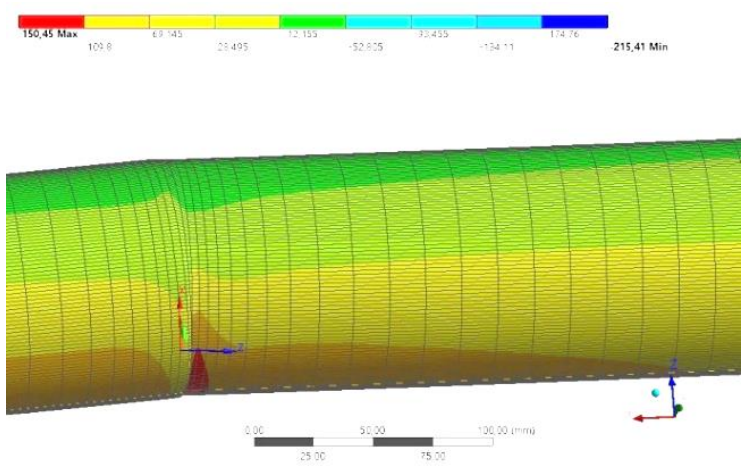

a

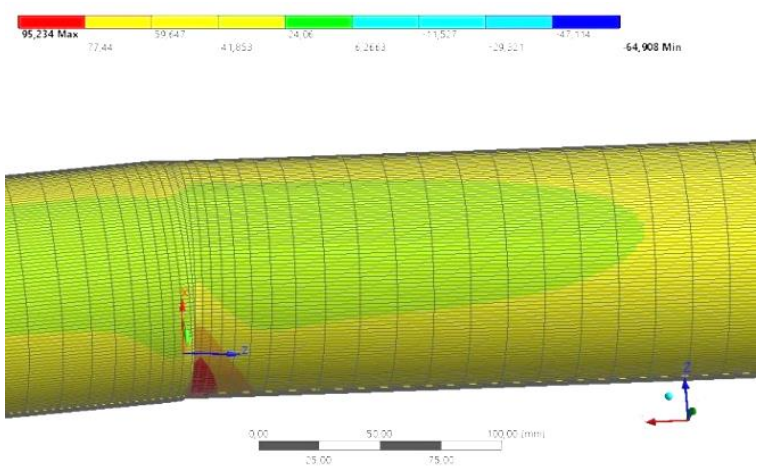

$\mathrm{b}$

Figure 2. Normal stresses under pressure: a) in axial direction; b) in circular direction

The stress distribution curves are similar in character, their divergence is related to additional moments occurring under numerical model loading but analytical expressions provide convenient tool for estimation of stresses in complex defect.

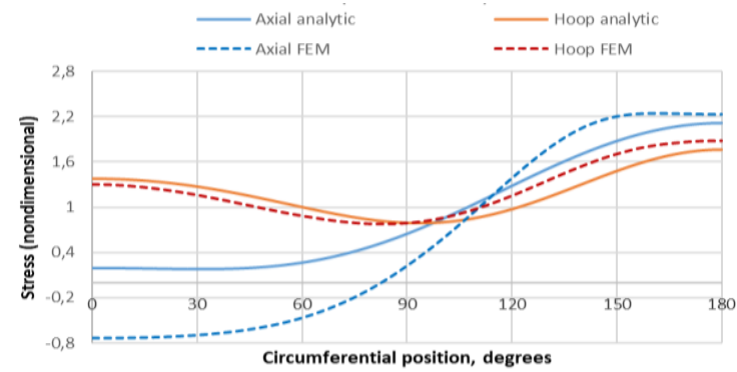

a

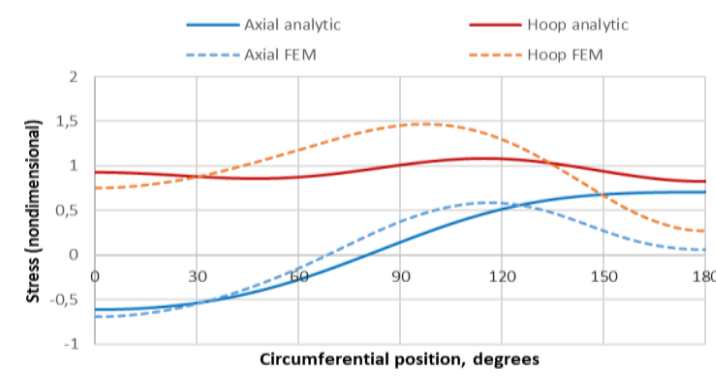

b

Figure 3. Distribution of axial and circumferential stresses: $a$ - on the outer surface, $b$ - on the inner surface

Conclusions. Concentration coefficients separately for angular and axial misalignment are obtained and SSS of complex defect as superposition of simple ones is proposed in this paper. The carried out numerical modeling of the shell under internal pressure focused on testing the results of analytical solution (where we confined ourselves to short solution) revealed certain results discrepancy in the stresses concentration areas. The curve distribution character is similar and the results discrepancy can be explained by smoothing joint area displacement and angular misalignment in numerical model as well as occurrence of certain 
local ones. However the obtained expressions for stress concentration coefficients are convenient for using in practical calculations.

\section{References}

1. Dubyk Ya. R., Seliverstova I. P., Bohdan A. V. Zastosuvannia poniat korotkoho ta dovhoho rishen teorii obolonok dlia analizu NDS truboprovodiv z kutovoiu nespivvisnistiu. Tekhnichni nauky ta tekhnolohii. 2019. № 1 (15). P. 21-30. [In Ukrainian]. https://doi.org/10.25140/2411-5363-2019-1(15)-21-30

2. Yaskovets Z. S., Seliverstova I. P., Borodii M. V. Local stress state of pipelines with misalignment connections. Mechanics and Advanced Technologies. 2019. № 1 (85). 35-40. [In Ukrainian]. https://doi.org/10.20535/2521-1943.2019.85.132114.

3. RD-23.040.00-KTN-090-07. Klassifikatsiya defektov i metodyi remonta defektov i defektnyih sektsiy deystvuyuschih magistralnyih nefteprovodov. OAO AK "Transneft". 2007.

4. Taraievskyi O. S. Doslidzhennia nesuchoi zdatnosti mahistralnykh truboprovodiv za skladnykh umov. Naftova i hazova promyslovist. 2014. № 5. P. 27-30. [In Ukrainian].

5. Sarulev A. L., Sarulev L. V. Prochnost oborudovaniya gazonefteprovodov i hranilisch. Tomsk: Tomskiy politehnicheskiy institute, 2013. $120 \mathrm{p}$.

6. Sosudyi, rabotayuschie pod davleniem, kotlyi i truboprovodyi: sbornik normativnyih dokumentov. M.: NTs ENAS, 2013. $528 \mathrm{p}$.

7. Orynyak I., Dubyk Y. Approximate Formulas for Cylindrical Shell Free Vibration Based on Vlasov's and Enhanced Vlasov's Semi-Momentless Theory: Proceedings of the ASME 2018 Pressure Vessels and Piping Conference PVP2018-84932, Czech Republic, July, 15-20, 2018. Prague, 2018. P. 10. https://doi.org/10.1115/PVP2018-84932

8. Dubyk Ya. R. and Seliverstova I. P. Application of the approximate solutions of the shell theory for the problem on concentrated force action on the hollow cylinder. Materials Science. 2019. № 2 (55). P. 96-103. https://doi.org/10.1007/s11003-019-00295-y

\section{Список використаної літератури}

1. Дубик Я. Р., Селіверстова І. П., Богдан А. В. Застосування понять короткого та довгого рішень теорії оболонок для аналізу НДС трубопроводів з кутовою не співвісністю. Технічні науки та технології. 2019. № 1 (15). С. 21-30. https://doi.org/10.25140/2411-5363-2019-1(15)-21-30

2. Ясковець 3. С.,Селіверстова І. П., Бородій М. В. Локальний напружений стан трубопроводів 3 неспіввісними з'єднаннями. Mechanics and Advanced Technologies. 2019. № 1 (85). С. 35-40. https://doi.org/10.20535/2521-1943.2019.85.132114.

3. РД-23.040.00-КТН-090-07. Классификация дефектов и методы ремонта дефектов и дефектных секций действующих магистральных нефтепроводов. ОАО АК «Транснефть». 2007.

4. Тарасвський О. С. Дослідження несучої здатності магістральних трубопроводів за складних умов. Нафтова і газова промисловість. 2014. № 5. С. 27-30.

5. Сарулев А. Л., Сарулев Л. В. Прочность оборудования газонефтепроводов и хранилищ. Томск: Томский политехнический інститут, 2013. 120 с.

6. Сосуды, работающие под давлением, котлы и трубопроводы: сборник нормативных документов. М.: НЦ ЭНАС, 2013. $528 \mathrm{c}$.

7. Orynyak I., Dubyk Y. Approximate Formulas for Cylindrical Shell Free Vibration Based on Vlasov's and Enhanced Vlasov's Semi-Momentless Theory: Proceedings of the ASME 2018 Pressure Vessels and Piping Conference PVP2018-84932, Czech Republic, July, 15-20, 2018. Prague, 2018. P. 10. https://doi.org/10.1115/PVP2018-84932.

8. Дубик Я. Р., Селіверстова І. П. Застосування наближених розв'язків теорії оболонок для задачі про дію зосередженої сили на порожнистий циліндр. Фізико - хімічна механіка матеріалів. 2019. № 2 (55). C. 96-103. https://doi.org/10.1007/s11003-019-00295-y 


\title{
УДК 539.4
}

\section{ЛОКАЛЬНИЙ НАПРУЖЕНИЙ СТАН ТРУБОПРОВОДУ 3 ОСЬОВОЮ ТА КУТОВОЮ НЕСПІВВІСНІСТЮ ЗВАРНОГО ШВА}

\author{
Ярослав Дубик ${ }^{1}$ І Ірина Селіверстова ${ }^{2}$
}

${ }^{1}$ ТОВ «ІПП-Центр», Київ, Украӥна

${ }^{2}$ Інститут проблем міџності імені Г. С. Писаренка НАН України, Київ, Украӥна

Резюме. Присвячено оцінюванню напруженого стану оболонки, яка містить в собі одночасно два поширених дефекти форми зварного шва - кутову та осьову неспіввісність.

Не зважаючи на достатню кількість публікачій за темою дефектів зварних швів, мало уваги приділялося такому складному дефекту зварного шва, як комбінація кутової та осьової неспіввісності. $B$ попередніх роботах було проаналізовано напружений стан труби окремо з кутовою неспіввісністю та осьовою неспіввісністю (різнотовщинністю зварювальних труб) на основі оболонкових рішень і отримано аналітичний метод визначення силових та деформачійних параметрів для аналізу напруженого стану трубопроводів з недосконалостями зварних швів.

Розроблено інженерний аналітичний метод визначення напруженого стану трубопроводу зі складним дефектом форми, який може бути представлений як комбінація простих. Тому отримано вирази для силових компонент й коефіцієнти концентрацій напружень окремо для осьової та кутової неспіввісностей. Аналіз трунтується на раніше розробленому понятті «короткого» рішення. Для верифікації запропонованого аналітичного методу побудовано скінченноелементну модель комбінованого дефекту зварного шва та виконано чисельний аналіз при дії внутрішнього тиску з використанням розрахункового комплексу ANSYS. Чисельне моделювання у порівнянні з аналітичною прочедурою демонструє розходження результатів у зоні концентрації напружень, в околі зварного шва, за рахунок виникнення локальних моментів у чисельній моделі. Проте запропоновані коефіцієнти концентрації напружень зручно використовувати у практичних розрахунках вказаних типів дефектів поперечного зварного шва, для швидкого оцінювання допустимості дефектів. Детальніше оцінювання напруженодеформованого стану дефекту, у випадку невиконання умов міцності за попереднім розрахунком, вимагає побудови чисельної моделі.

Ключові слова: осьова неспіввісність, кутова неспіввісність, коефіцієнт концентрації напружень, метод скінченних елементів, циліндрична оболонка. 